\title{
Analyses of the Menstrual Cycle Variabilities of the Human Epididymis Protein 4
}

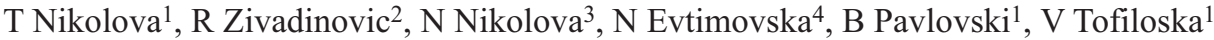

\begin{abstract}
The purpose of this study was to examine the menstrual cycle variabilities or variations in the Human Epididymis Protein 4 (HE4) serum levels in women with benign ovarian diseases. A prospective study was done at the University Clinic of Obstetrics and Gynaecology in Skopje. Ninety-four patients divided into two groups: 37 patients with ovarian endometriosis and 57 patients with the "other benign pelvic masses" were included in the study. After the ultrasound finding of a pelvic mass with a possible ovarian origin, all the patients were serum sampled for HE4 and carbohydrate antigen-125 (CA125). All the cases underwent surgical removal of the mass with subsequent histologic evaluation which was referent for the group classification. There were no significant differences in the HE4 in the blood levels between the follicular (FP) and the luteal phases (LP) in the patients with ovarian endometriosis $(t 35=0.147, \mathrm{p}=0.884)$ and the "other benign pelvic masses" $(U=424.5, \mathrm{p}=0.730)$. There were no significant differences in the HE4 serum levels in the follicular phase between the two groups $(U=222.0, \mathrm{p}=0.266)$ and in the luteal phase. The difference in the HE4 serum levels between the two groups (Mdn 40.20 vs $35.50 \mathrm{pmol} / \mathrm{L}), U=469.5, \mathrm{p}=0.048$, was statically significant. Hence, HE4 is a robust biochemical marker and could be tested irrespective of the variations in the menstrual cycle.
\end{abstract}

Keywords: Human Epididymis Protein 4 (HE4), menstrual cycle, variability

\section{Análisis de las Variabilidades del Ciclo Menstrual de la Proteína Humana del Epidídimo 4}

\author{
T Nikolova ${ }^{1}$, R Zivadinovic $^{2}, \mathrm{~N}_{\text {Nikolova }}{ }^{3}, \mathrm{~N}_{\text {Evtimovska }}{ }^{4}$, B Pavlovski ${ }^{1}, \mathrm{~V}_{\text {Tofiloska }}{ }^{1}$
}

\begin{abstract}
RESUMEN
El propósito de este estudio fue examinar las variabilidades del ciclo menstrual o las variaciones en los niveles séricos de HE4 en mujeres con enfermedades ováricas benignas. Se realizó un estudio prospectivo en la Clínica Universitaria de Obstetricia y Ginecología en Skopje. Noventa y cuatro pacientes divididos en dos grupos fueron incluidos en el estudio. Un grupo estuvo formado por 37 pacientes con endometriosis ovárica, y el otro por 57 pacientes con "otras masas pélvicas benignas". Luego de la detección ultrasónica de una masa pélvica de posible origen ovárico, se obtuvieron muestras de todos los pacientes para investigar el comportamiento sérico de HE4 y CA125. Todos los casos fueron sometidos a cirugía para retirar la masa pélvica, además de la subsecuente evaluación histológica como criterio para la clasificación en grupos. No hubo diferencias significativas de HE4 en los niveles sanguíneos entre las fases folicular (FF) y lútea (FL) en los pacientes con endometriosis ovárica ( $t 35=0.147$, $\mathrm{p}=0.884)$ y las "otras masas pélvicas benignas" $(U=424.5, \mathrm{p}=0.730)$. No hubo diferencias significati-vas en los niveles séricos de HE4 en la fase folicular entre los dos grupos $(U=222.0, \mathrm{p}=$ 0.266) y en la fase lútea. La diferencia en los niveles séricos de HE4 entre los dos grupos (Mdn 40.20 vs $35.50 \mathrm{pmol} / \mathrm{L}), U=469.5, \mathrm{p}=0.048$, fue estadísticamente significativa. Por lo tanto, HE4 es un marcador bioquímico robusto y podía ser probado independientemente de las variaciones en el ciclo menstrual.
\end{abstract}

Palabras claves: Proteína humana del epidídimo 4 (HE4), ciclo menstrual, variabilidad

West Indian Med J 2017; 66 (1): 83

From: ${ }^{1}$ University Clinic of Obstetrics and Gynaecology, Skopje, Republic of Macedonia, ${ }^{2}$ Clinic of Obstetrics and Gynaecology, University Clinical Centre, Nis, Republic of Serbia, ${ }^{3}$ Medical School, University Ss. Cyril and Methodius, Skopje, Republic of Macedonia, and ${ }^{4}$ University Clinic of Oncology and Radiotherapy, Skopje, Republic of Macedonia.
Correspondence: Dr T Nikolova, Pirinska 106A 2000 Shtip, Republic of Macedonia. Email: nikolovatanja@gmail.com 


\section{INTRODUCTION}

Ovarian cancer is a common gynaecologic cancer with a worse prognosis if detected in the advanced stages. The estimated annual incidents are 238700 cases worldwide and 151900 patients die every year under the diagnosis of ovarian cancer (1). Carbohydrate antigen-125 marker is a far widely used biomarker in the management of women with an adnexal mass, but it shows low specificity, being elevated in benign ovarian diseases, gynaecological and some nongynaecological cancers, as well as in liver diseases (2-4). Furthermore, it has been reported to show menstrual cycle variabilities (5).

The novel biomarker HE4 (human epididymis protein 4) is a member of the family of whey acidic proteins. Over-expression of the HE4 has been found in serous and endometrioid ovarian carcinoma (6). Its use has been intensively studied and has been shown to overcome the classification power of CA125 $(7,8)$. Previous studies have shown: age, fertility status, menopause, smoking, ethnicity and renal function may affect serum HE4 levels (9-11).

The primary aim of this study was to examine the menstrual cycle variabilities of serum HE4 levels in women with benign ovarian pathology.

\section{SUBJECTS AND METHODS}

A prospective, observational study was conducted at the University Clinic of Obstetrics and Gynaecology in Skopje. The study was approved by the Ethics committee at the Ministry of Health in the Republic of Macedonia. Only patients who agreed to sign the informed consent were included in the trial. Ninety-four premenopausal women were included in this study. They were separated into two groups: 37 with ovarian endometriosis, and 57 with "other benign pelvic masses". To be eligible for enrolment in this study, all the patients were required to be 18 years of age or older with regular menstrual cycles, to have an ultrasonography scan showing an ovarian mass and to be scheduled for a surgical intervention. From this study, patients younger than 18 years with irregular menstrual cycles, patients with prior oophorectomies, patients with current or past malignancy, renal failure or disease, current hormonal therapy and pregnancy, were excluded. Histology finding was referent for the group classification.

Ultrasound investigation was performed using Voluson E8 (General Electrics), 4-9 MHz RIC5-9D vaginal transducers in each patient in supine position. Ultrasonography was performed at most six weeks prior to the surgical intervention. Sera samples were analysed using the Architect CA125 II and Architect HE4 reagents on an Abbott Platform (Abbott Diagnostics, Wiesbaden, Germany) and following the manufacturer's instructions. All the patients underwent surgical removal of the ovarian mass.

Statistical analyses were carried out using the following software SPSS 22.0 (IBM Corp. Released 2013. Armonk, NY). The statistical tests used in the analyses were as follows: Man Whitney U test, Pearson correlation, Spearman rank correlation and $t$-test. The level of significance $\alpha$ was set at $5 \%$.

\section{RESULTS}

We examined 94 patients who were divided into two groups. The first group included 37 (39.4\%) patients with endometriosis and the second group included 57 (60.6\%) patients with the "other benign pelvic masses". Out of the patients, $15(26.3 \%)$ had epithelial, $19(33.3 \%)$ had functional, $4(7.0 \%)$ had germinative, $13(22.8 \%)$ had inflammatory tumours, $2(3.5 \%)$ had uterine myomas, 3 $(5.3 \%)$ had paraovarial and $1(1.8 \%)$ had stromal tumour. Descriptive statistics were shown in Table 1.

Table 1: Descriptive statistics for endometriosis and "other benign pelvic masses"

\begin{tabular}{|c|c|c|c|c|c|c|c|}
\hline \multirow[b]{2}{*}{$n(\%)$} & \multirow[b]{2}{*}{ Range } & \multicolumn{3}{|c|}{ ENDOMETRIOSIS } & \multirow[b]{2}{*}{$\begin{array}{c}\text { Smoker } \\
n(\%)\end{array}$} & \multirow[b]{2}{*}{$\begin{array}{c}\text { Follicular } \\
\text { phase } \\
n(\%)\end{array}$} & \multirow[b]{2}{*}{$\begin{array}{c}\text { Luteal phase } \\
n(\%)\end{array}$} \\
\hline & & $\begin{array}{c}\text { Age (years) } \\
M\end{array}$ & $S D$ & $\begin{array}{c}\text { Nonsmoker } \\
n(\%)\end{array}$ & & & \\
\hline \multirow[t]{2}{*}{$37(39.4)$} & $19-49$ & 34.70 & 8.58 & $24(64.9)$ & $13(35.1)$ & $14(37.8)$ & $23(62.2)$ \\
\hline & & Range & $M$ & $S D$ & $M d n$ & Skewness (SE) & Kurtosis (SE) \\
\hline Weight & $\mathrm{Kg}$. & $54.0-76.0$ & 65.65 & 5.14 & 65.00 & $-.032(0.39)$ & $0.22(0.76)$ \\
\hline BMI & & $19.6-27.1$ & 23.71 & 2.05 & 23.18 & $-0.19(0.39)$ & $-0.76(0.76)$ \\
\hline HE4 & $\mathrm{pmol} / \mathrm{L}$ & $14.4-56.8$ & 37.12 & 10.00 & 35.50 & $0.16(0.39)$ & $-0.03(0.76)$ \\
\hline CA125 & $\mathrm{U} / \mathrm{mL}$ & $10.2-172.4$ & 57.89 & 47.18 & 35.40 & $1.01(0.39)$ & $-0.12(0.76)$ \\
\hline \multicolumn{8}{|c|}{ Follicular phase } \\
\hline HE4 & $\mathrm{pmol} / \mathrm{L}$ & $20.4-56.8$ & 37.44 & 10.63 & 36.00 & $0.245(0.60)$ & $-0.236(1.15)$ \\
\hline CA125 & $\mathrm{U} / \mathrm{mL}$ & $11.2-172.4$ & 71.02 & 53.70 & 52.60 & $0.551(0.60)$ & $-0.961(1.15)$ \\
\hline \multicolumn{8}{|c|}{ Luteal phase } \\
\hline HE4 & $\mathrm{pmol} / \mathrm{L}$ & $14.4-56.2$ & 36.93 & 9.84 & 35.50 & $0.102(0.48)$ & $0.407(0.94)$ \\
\hline CA125 & $\mathrm{U} / \mathrm{mL}$ & $10.2-162.3$ & 49.89 & 41.98 & 28.80 & $1.405(0.48)$ & $1.200(0.94)$ \\
\hline
\end{tabular}


“OTHER BENIGN PELVIC MASSES"

\begin{tabular}{|c|c|c|c|c|c|c|c|}
\hline$n(\%)$ & Range & $\begin{array}{c}\text { Age (years) } \\
M\end{array}$ & $S D$ & $\begin{array}{c}\text { Nonsmoker } \\
n(\%)\end{array}$ & $\begin{array}{c}\text { Smoker } \\
n(\%)\end{array}$ & $\begin{array}{c}\text { Follicular } \\
\text { phase } \\
n(\%)\end{array}$ & $\begin{array}{c}\text { Luteal phase } \\
n(\%)\end{array}$ \\
\hline \multirow[t]{2}{*}{$57(60.6)$} & $18-50$ & 36.90 & 10.12 & $33(57.9)$ & $24(42.1)$ & $26(45.6)$ & $31(54.4)$ \\
\hline & & Range & $M$ & $S D$ & $M d n$ & Skewness (SE) & Kurtosis (SE) \\
\hline Weight & $\mathrm{Kg}$. & $48.0-94.0$ & 64.81 & 8.64 & 64.00 & $0.51(0.32)$ & $1.32(0.62)$ \\
\hline BMI & & $18.0-47.96$ & 23.88 & 4.2 & 23.94 & $3.31(0.32)$ & $18.67(0.62)$ \\
\hline HE4 & $\mathrm{pmol} / \mathrm{L}$ & $15.4-163.9$ & 49.62 & 27.87 & 40.30 & $2.51(0.32)$ & $7.73(0.62)$ \\
\hline CA125 & $\mathrm{U} / \mathrm{mL}$ & $5.4-1326.4$ & 95.13 & 221.01 & 27.50 & $4.53(0.32)$ & $21.73(0.62)$ \\
\hline \multicolumn{8}{|c|}{ Follicular phase } \\
\hline HE4 & $\mathrm{pmol} / \mathrm{L}$ & $15.4-163.9$ & 48.65 & 29.11 & 41.40 & $2.70(0.46)$ & $9.56(0.89)$ \\
\hline CA125 & $\mathrm{U} / \mathrm{mL}$ & $5.4-457.8$ & 86.14 & 100.24 & 40.20 & $2.24(0.46)$ & $6.63(0.89)$ \\
\hline \multicolumn{8}{|c|}{ Luteal phase } \\
\hline HE4 & $\mathrm{pmol} / \mathrm{L}$ & $22.2-157.8$ & 50.43 & 27.24 & 40.20 & $2.47(0.42)$ & $7.68(0.82)$ \\
\hline CA125 & $\mathrm{U} / \mathrm{mL}$ & $8.0-1326.4$ & 102.68 & 287.53 & 22.90 & $3.81(0.42)$ & $13.91(0.82)$ \\
\hline
\end{tabular}

BMI: body mass index; M: mean; SD: standard deviation; Mdn: median; SE: standard error; ASRM: American Society of Reproductive Medicine; HE4: human epididymis protein 4; CA125: carbohydrate antigen-125

The difference in the level of the marker HE4 and CA125 between the patients with endometriosis and "other benign pelvic masses" was tested. For the patients with endometriosis $(\mathrm{n}=37)$, marker HE4 was associated with lower level $(\mathrm{Mdn}=35.50) \mathrm{pmol} / \mathrm{L}$ in comparison with patients with "other benign pelvic masses" $(n=57)$ where marker HE4 was associated with higher level $(\mathrm{Mdn}=40.30) \mathrm{pmol} / \mathrm{L}$. To test if there was a significant difference in the level of the marker HE4 between the two groups, a non-parametric Mann-Whitney $\mathrm{U}$ test was done.

Shapiro-Wilk's test $(p<0.05)$, an inspection of the skew-ness and kurtosis measures, visual inspection of their his-tograms, normal Q-Q plots and box plots showed that the sample data were not normally distributed. A nonparametric Levene's test was used to verify the homogeneity of the vari-ance $(p=0.119)$. This difference was significant $(\mathrm{U}=752.5, p=0.019$ two-tailed). The Glass rank biserial correlation $=0.286$, with a small effect in Cohen's (1988) classification (Fig. 1).

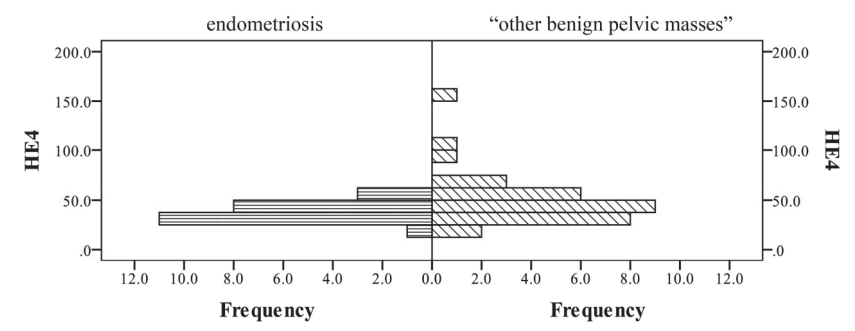

Fig 1: Population pyramid for marker HE4, endometriosis / "other benign pelvic masses".

On the contrary, for the marker CA125, there was a difference in the level between the patients with endometriosis $(\mathrm{Mdn}=35.40) \mathrm{U} / \mathrm{mL}$ in comparison with the patients with the "other benign pelvic masses" $(\mathrm{Mdn}=27.50) \mathrm{U} / \mathrm{mL}$. The
Mann-Whitney $\mathrm{U}$ test done showed that this difference was not significant ( $\mathrm{U}=1,218.5, p=0.204$, two-tailed).

There was a difference in the level of the marker HE4 between the follicular phase of the menstrual cycle and the luteal phase of the menstrual cycle for the patients with endometriosis and the "other benign pelvic masses". To test the hypothesis that level of the marker HE4 $(\mathrm{M}=37.44 \mathrm{pmol} / \mathrm{L}$ follicular, $\mathrm{M}=36.93 \mathrm{pmol} / \mathrm{L}-$ luteal) is different for the phases of menstrual cycle for the patients with endometrioses, an independent $t$-test was performed which was statistically not significant ( $\mathrm{t}(35)=0.147, p=0.884$, two-tailed). For the "other benign pelvic masses" $(\mathrm{Med}=41.40 \mathrm{pmol} / \mathrm{L}-$ follicular, Med $=40.20 \mathrm{pmol} / \mathrm{L}-$ luteal) a non-parametric Mann-Whitney $\mathrm{U}$ test was performed which was also statistically not significant ( $\mathrm{U}=424.5, p=0.730$, two-tailed).

Tested differences for the maker CA125 between the follicular phase and the luteal phase of the menstrual cycle for the patients with endometrioses $(\mathrm{M}=71.02 \mathrm{U} / \mathrm{mL}$ - follicular, $\mathrm{M}=48.89 \mathrm{U} / \mathrm{mL}$ - luteal) and for the "other benign pelvic masses" $(\mathrm{Med}=40.20 \mathrm{U} / \mathrm{mL}-$ follicular, Med $=22.90 \mathrm{U} / \mathrm{mL}$ - luteal), were statistically not significant ( $\mathrm{t} 35=1.336, p=$ 0.19 , two-tailed) for the patients with endometriosis, and ( $\mathrm{U}$ $=289.5, p=0.069$, two-tailed) for the patients with the "other benign pelvic masses".

For the phases of the menstrual cycle, follicular and luteal, we tested the difference in the level of the marker HE4 and the marker CA125 between the patients with endometriosis and the "other benign pelvic masses". For the phases of the menstrual cycle, to test the hypothesis that the level of marker HE4 for the patients with endometriosis $(\mathrm{n}=14)$, (Mdn $=36.00 \mathrm{pmol} / \mathrm{L}-$ follicular phase $)$ and $(\mathrm{n}=23),(\mathrm{Mdn}=35.50$ $\mathrm{pmol} / \mathrm{L}$ - luteal phase) was significantly different for the patients with the "other benign pelvic masses" $(\mathrm{n}=26)$, $(\mathrm{Mdn}=41.40 \mathrm{pmol} / \mathrm{L}-$ follicular phase $)$ and $(\mathrm{n}=31),(\mathrm{Mdn}=$ $40.20 \mathrm{pmol} / \mathrm{L}$ - luteal phase), respectively, a non-parametric 
Mann-Whitney test was performed. Shapiro-Wilk's test $(p<0.05)$, inspection of the skewness and kurtosis measures, visual inspection of their histograms, normal Q-Q plots and box plots showed that the sample data were not normally distributed for both phases. A non-parametric Levene's test was used to verify the homogeneity of the variance $(p=0.205)$ for the follicular phase and $(p=0.387)$ for the luteal phase. The follicular phase difference was not significant: $(\mathrm{U}=222.0 ; p$ $=0.266$ (exact significance, two-tailed), while for the luteal phase level of the marker HE4 for "other benign pelvic masses" ( $\mathrm{Mdn}=40.20) \mathrm{pmol} / \mathrm{L}$ was significantly higher than the level for endometriosis $(\mathrm{Mdn}=35.50) \mathrm{pmol} / \mathrm{L}$ $(\mathrm{U}=469.5, p=0.048$, two-tailed). The Glass rank biserial correlation was 0.317 , suggesting a medium effect based on Cohen's (1988) classification (Fig. 2).

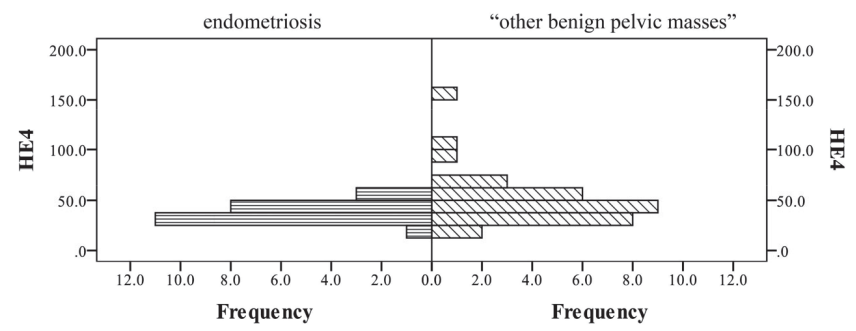

Fig. 2: Population pyramid for marker HE4, endometriosis/"other benign pelvic masses" for the luteal phase of the menstrual cycle.

The difference in the level of the marker CA125 between endometriosis, and the "other benign pelvic masses" was not significant for both phases: $(\mathrm{U}=173.0, p=0.812)$ [exact significance, two-tailed] for the follicular phase, and $\mathrm{U}=$ 250.5, $p=0.064$ (two-tailed) for the luteal phase.

The correlations among markers HE4 and CA125 for the patients with endometriosis in the follicular phase of the menstrual cycle and the luteal phase of the menstrual cycle are shown in Table 2. Both correlations are not significant $p=$ 0.398 for the follicular phase, $p=0.648$ for the luteal phase.

Table 2: Spearman rank correlations for endometriosis, follicular and luteal phases of the menstrual cycle

\begin{tabular}{lcc}
\hline \multicolumn{1}{c}{ Correlation HE4/CA125 } & Pearson $\mathbf{r}$ & $\boldsymbol{p}$-value \\
\hline $\begin{array}{l}\text { Endometriosis and follicular phases of the } \\
\text { menstrual cycle }\end{array}$ & $\mathrm{r}(12)=0.245$ & 0.398 \\
$\begin{array}{l}\text { Endometriosis and luteal phases of the } \\
\text { menstrual cycle }\end{array}$ & $\mathrm{r}(21)=0.101$ & 0.648 \\
\hline
\end{tabular}

The correlations among markers HE4 and CA125 for the patients with the "other benign pelvic masses" in the follicular phase of the menstrual cycle and the luteal phase of the menstrual cycle are shown in Table 3.

The correlation between HE4 and CA125 in the follicular phase of the menstrual cycle is significant $p=0.020$, while the correlation in the luteal phase is not significant $(p=0.236)$.

Figure 3, shows the scatter plot for the levels of the marker HE4 for the cases where marker CA125 was abnormally
Table 3: Spearman rank correlations for "other benign pelvic masses", follicular and luteal phases of the menstrual cycle

\begin{tabular}{lcc}
\hline \multicolumn{1}{c}{ Correlation HE4 / CA125 } & Spearman rank $\mathbf{r}_{\mathrm{s}}$ & $\boldsymbol{p}$-value \\
\hline $\begin{array}{l}\text { "Other benign pelvic masses" and } \\
\text { follicular phase of the menstrual cycle }\end{array}$ & $\mathrm{r}_{\mathrm{s}}(24)=0.455$ & $<0.020^{*}$ \\
"Other benign pelvic masses" and & $\mathrm{r}_{\mathrm{s}}(29)=0.219$ & $>0.236$ \\
\hline
\end{tabular}

$* p<0.05$ significant

raised ( $>35 \mathrm{U} / \mathrm{mL})$. As we can see from the scatter plot, only in four cases was the level of the marker HE4 above $70 \mathrm{pmol} /$ $\mathrm{L}$ and all the cases were from the "other benign pelvic masses" group. Of the four cases, two were epithelial tumours, one was an inflammatory tumour and one case was a uterine myoma. Two cases each were in the follicular and the luteal phases of the menstrual cycle.

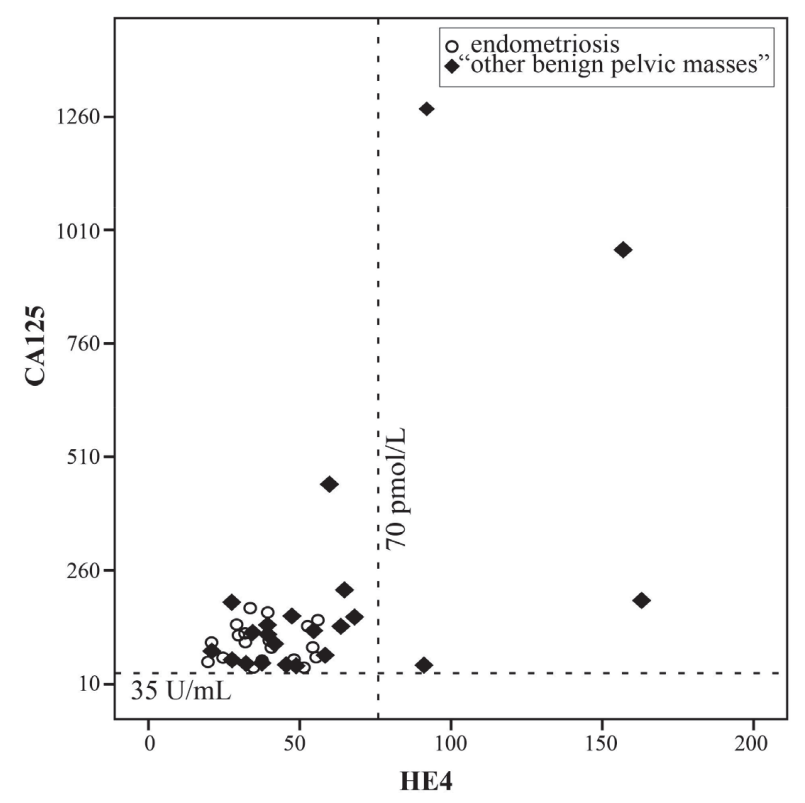

Fig. 3: Scatterplot of the benign pelvic masses HE4 vs CA125 for CA125 > 35, for the benign tumours.

\section{DISCUSSION}

In this study, we found that HE4 had a higher median in women with the "other benign pelvic mass" group in comparison with those with endometriosis (40.30 vs $35.50 \mathrm{pmol} / \mathrm{L})$, and this difference was statistically significant $(p<0.05)$. Among the patients with abnormal CA125 levels $(>35 \mathrm{U} / \mathrm{mL})$, we detected four patients with HE4 levels above $70 \mathrm{pmol} / \mathrm{L}$ and all of them represented the "other benign pelvic mass" group. Of these four cases, two were epithelial cystadenomas, one was an ovarian abscess, and one was uterine myoma. For the patients with epithelial cystadenomas, the level of HE4 was double and its upper referent value was $70 \mathrm{pmol} / \mathrm{L}$ whereas CA 125 was almost 30 times higher than its upper referent value $(35 \mathrm{U} / \mathrm{mL})$. Similarly, for the patient with uterine myoma, 
a slightly elevated level of HE4 went along with 40 times higher CA125.

Furthermore, our analyses showed that the menstrual cycle did not affect the variations in the HE4 serum levels in both groups (ie the patients with endometriosis and the "other benign pelvic mass". This is in line with the findings already reported for the patients with endometriosis (12). Mckinnon et al came to the same conclusions regarding women with endometriosis, but they analysed HE4 from the peritoneal fluid (13). However, Anastasi et al study of 40 women divided into two groups, reported menstrual cycle phase-dependent variability, but only for women under the age of 35 years (14).

To our knowledge, our study is one of the first to investigate the menstrual cycle variations in patients with a benign ovarian disease, other than endometriotic tumours. The present study demonstrates that HE4 testing in women with ovarian endometriosis, as well as in women with the rest of benign ovarian pathology, can be carried out in any phase of the menstrual cycle, extending the benefits of HE4 use in clinical practice. We have performed the same analyses for CA125 serum levels and concluded that CA125 can be measured regardless of the variations irrespective in the menstrual cycle. On comparing the HE4 serum levels in the follicular and luteal phases among the patients with ovarian endometriosis and the "other benign pelvic mass", we found higher HE4 levels in the luteal phase in the patients with the "other benign pelvic mass" than in the patients with endometriosis, and this difference was statistically significant. No statistical significance was detected for CA125.

\section{CONCLUSION}

Human epididymis protein 4; is a robust biochemical marker and could be tested regardless of the variations in the human menstrual cycle.

\section{REFERENCES}

1. Torre LA, Bray F, Siegel RL, Ferlay J, Lortet-Tieulent J, Jemal A. Global cancer statistics. 2012; CA Cancer J Clin 2015; 65: 87-108.

2. Buamah P. Benign conditions associated with raised serum CA-125 concentration. J Surg Oncol 2000; 75: 264-5.

3. Jacobs I, Bast RC. The CA 125 tumour-associated antigen: a review of the literature. Hum Reprod Oxf Engl 1989; 4: 1-12.

4. Haga Y, Sakamoto K, Egami H, Yoshimura R, Mori K, Akagi M. Clinical significance of serum CA125 values in patients with cancers of the digestive system. Am J Med Sci 1986; 292: 30-4.

5. Kan YY, Yeh SH, Ng HT, Lou CM. Effect of menstruation on serum CA125 levels. Asia-Ocean J Obstet Gynaecol 1992; 18: 339-43.

6. Drapkin R, von Horsten HH, Lin Y, Mok SC, Crum CP, Welch WR et al. Human epididymis protein 4 (HE4) is a secreted glycoprotein that is overexpressed by serous and endometrioid ovarian carcinomas. Cancer Res 2005; 65: 2162-9.

7. Montagnana M, Lippi G, Ruzzenente O, Bresciani V, Danese E, Scevarolli $\mathrm{S}$ et al. The utility of serum human epididymis protein 4 (HE4) in patients with a pelvic mass. J Clin Lab Anal 2009; 23: 331-5.

8. Moore RG, Brown AK, Miller MC, Skates S, Allard WJ, Verch T et al. The use of multiple novel tumor biomarkers for the detection of ovarian carcinoma in patients with a pelvic mass. Gynecol Oncol 2008; 108: 402 8.

9. Ferraro S, Schiumarini D, Panteghini M. Human epididymis protein 4: factors of variation. Clin Chim Acta Int J Clin Chem 2015; 438: 171-7.

10. Moore RG, Miller MC, Eklund EE, Lu KH, Bast RC, Lambert-Messerlian G. Serum levels of the ovarian cancer biomarker HE4 are decreased in pregnancy and increase with age. Am J Obstet Gynecol 2012; 206: $349-7$.

11. Karlsen NS, Karlsen MA, Høgdall CK, Høgdall EVS. HE4 tissue expression and serum HE4 levels in healthy individuals and patients with benign or malignant tumors: a systematic review. Cancer Epidemiol Biomark Prev 2014; 23: 2285-95.

12. Hallamaa M, Suvitie P, Huhtinen K, Matomäki J, Poutanen M, Perheentupa A. Serum HE4 concentration is not dependent on menstrual cycle or hormonal treatment among endometriosis patients and healthy premenopausal women. Gynecol Oncol 2012; 125: 667-72.

13. Mckinnon B, Mueller MD, Nirgianakis K, Bersinger NA. Comparison of ovarian cancer markers in endometriosis favours HE4 over CA125. Mol Med Rep 2015; 12: 5179-84.

14. Anastasi E, Granato T, Marchei GG, Viggiani V, Colaprisca B, Comploj $\mathrm{S}$ et al. Ovarian tumor marker HE4 is differently expressed during the phases of the menstrual cycle in healthy young women. Tumour Biol 2010; 31: 411-5. 